\title{
Originals
}

\section{Venous Oxygenation in the Diabetic Neuropathic Foot: Evidence of Arteriovenous Shunting?}

\author{
A.J. M. Boulton, J. H. B. Scarpello and J, D. Ward \\ Royal Hallamshire Hospital, Sheffield, UK
}

Summary. Venous $\mathrm{PO}_{2}$ was measured in the feet and hands of four subject groups: 14 diabetics with neuropathy and foot ulceration; 12 diabetics with neuropathy but no ulceration; 11 diabetics with no evidence of microvascular complications; and 10 nondiabetic controls. Neither patients nor controls had clinical evidence of peripheral vascular disease. The mean venous $\mathrm{PO}_{2}$ in the feet of subjects with neuropathy and foot ulceration was significantly higher than in controls or the other two diabetic groups. Venous $\mathrm{PO}_{2}$ in the feet of the subjects with ulcers was also significantly higher than in their hands or in the hands of the other groups. These results provide further evidence of abnormal blood flow in the diabetic neuropathic foot and are compatible with arteriovenous shunting.

Key words: Diabetic neuropathy, foot ulcers, arteriovenous anastomoses, venous oxygenation.

Diabetic patients with non-infected neuropathic foot ulcers frequently have prominent pedal arteries and distended dorsal foot veins, both in the ulcerated and in the non-ulcerated foot. Such patients also have increased blood flow in the lower limbs as suggested by plethysmographic [1] and ultrasound [2] studies. These observations led us to suggest that arteriovenous $(A-V)$ shunting in the diabetic neuropathic foot may be important in the pathogenesis of ulceration [3]. Shunting would result in both a reduction of the normal A-V oxygen saturation gradient in the peripheral vessels of such patients and increased venous oxygenation.

In order to investigate this further we have measured venous oxygenation, as determined by partial pressure of oxygen $\left(\mathrm{PO}_{2}\right)$, in the feet of diabetics with and without foot ulceration and neuropathy.

\section{Subjects and Methods}

\section{Subjects}

Thirty-seven diabetic and ten non-diabetic control subjects took part in the study, which was approved by the Hospital Ethical Committee. Informed consent was obtained in each case.

The subjects were divided into four groups (Table 1). Groups A and $B$ consisted of patients with typical symptoms and signs of peripheral neuropathy (paraesthesiae, burning pains, decreased vibration sensation, absent ankle reflexes) and reduced motor conduction velocity along the peroneal nerve of less than $40 \mathrm{~m} / \mathrm{s}$. The duration of neuropathic symptoms ranged from 1-8 years. Those in group A had active or recently healed foot ulcers on one or both feet at the time of study; none had clinical evidence of infection, no pathogenic organisms were cultured, and all were afebrile. Subjects in group B gave no history of foot ulceration. Group C consisted of diabetic patients with no clinical evidence of retinopathy or neuropathy, and all had normal peroneal nerve motor conduction velocities ( $>40 \mathrm{~m} / \mathrm{s})$. The diabetic subjects were matched for age, duration and type of diabetes. In these three groups the quality of blood glucose control was equivalent as assessed by comparison of mean values for the four preceding clinic visits (group A $11.1 \pm$ $0.9 \mathrm{mmol} / 1$, mean $\pm \mathrm{SEM} ;$ group B $11.2 \pm 1.24 \mathrm{mmol} / \mathrm{l}$; group $\mathrm{C}$

Table 1. Patient groups

\begin{tabular}{llll}
\hline Group & $\begin{array}{l}\text { No. of subjects } \\
\text { (insulin- } \\
\text { dependent) }\end{array}$ & $\begin{array}{l}\text { Mean age } \\
\text { in years } \\
\text { (range) }\end{array}$ & $\begin{array}{l}\text { Mean duration } \\
\text { of diabetes in } \\
\text { years (range) }\end{array}$ \\
\hline $\begin{array}{l}\text { A. Diabetics } \\
\text { with neuropathy } \\
\text { and foot ulcers }\end{array}$ & $(10)$ & 52 & 15 \\
$\begin{array}{l}\text { B. Diabetics } \\
\text { with neuropathy }\end{array}$ & 12 & $(27-68)$ & $(1-33)$ \\
$\begin{array}{l}\text { but no foot } \\
\text { ulcers }\end{array}$ & 51 & 14 \\
$\begin{array}{l}\text { C. Diabetics } \\
\text { with no } \\
\text { complications }\end{array}$ & 11 & $(30-70)$ & $(6-30)$ \\
$\begin{array}{l}\text { D. Non-diabetic } \\
\text { controls }\end{array}$ & 10 & 50 & \\
\hline
\end{tabular}


$12.2 \pm 1.2 \mathrm{mmol} / \mathrm{l}$ ), and none had suffered recent episodes of ketoacidosis. At the time of study, blood glucose was again similar with no significant differences between the diabetic groups. In addition, a control group (D) of 10 non-diabetic subjects was studied. The majority of these were awaiting minor surgical procedures and none had glycosuria or gave a family history of diabetes.

None of the patients or controls had symptoms or signs of hypertension, peripheral vascular disease or varicose veins, and none was anaemic (haemoglobin $>12 \mathrm{~g} / \mathrm{dl}$ ). All had ankle pressure indices [4] greater than unity. In addition, none of the subjects had symptoms of autonomic dysfunction (nocturnal diarrhoea, postural syncope, hypoglycaemic unawareness, abnormal sweating, bladder dysfunction), and all had a Valsalva ratio [5] of $>1.21$, with the exception of three patients who had ratios between 1.1 and 1.2. They were taking no drugs other than insulin or hypoglycaemic agents. All were non-smokers apart from two subjects in groups B and $\mathrm{C}$, and none smoked in the $3 \mathrm{~h}$ before the study.

\section{Procedures}

The studies were all performed in the afternoon, $2 \mathrm{~h}$ after lunch. Blood glucose was measured (Technicon autoanalyser) in the diabetics before the study and urine was tested for ketones.

All investigations were carried out in a warm room $\left(23^{\circ}-25^{\circ} \mathrm{C}\right)$ with the patients supine. After an initial 30-min period of stabilization, veins on the dorsum of each foot (usually on the medial side of the dorsal venous system) and on the back of the hand were cannulated using a Butterfly infusion set, $0.8 \mathrm{~mm}$ gauge. Venous occlusion was not applied in any subject. Blood was withdrawn from each site into a heparinised glass syringe for immediate analysis of $\mathrm{PO}_{2}$ using an Instrumentation Laboratories $\mathrm{pH} /$ blood gas analyser 313. Samples were taken from both feet, though in two patients in group $A$ it was possible to sample from only one foot for technical reasons. Three samples were taken from each site over a period of $20 \mathrm{~min}$.

Results were analysed using Student's ' $t$ ' test for paired and non-paired samples.

\section{Results}

There was no significant difference between the mean blood glucose levels in group A $(10.9 \pm 0.4 \mathrm{mmol} / 1$, mean $\pm \mathrm{SEM})$; group $\mathrm{B}(11.4 \pm 1.1 \mathrm{mmol} / \mathrm{l})$ and group $\mathrm{C}(11.2 \pm 1.1 \mathrm{mmol} / \mathrm{l})$, and none had ketonuria.

The mean venous $\mathrm{PO}_{2}$ results in the hands and feet of all groups are shown in Table 2. For groups B, C, D, results are expressed as the mean of the average values in both feet. Within group $\mathrm{A}$, the results for the ulcerated, non-ulcerated, and healed feet are also shown separately.

In the hand no significant difference in venous $\mathrm{PO}_{2}$ was found between any of the groups studied. In contrast, the mean venous $\mathrm{PO}_{2}$ in the feet of each of the three diabetic groups ( $\mathrm{A}, \mathrm{B}$ and $\mathrm{C}$ ), including the ulcerated, non-affected and healed feet in group A, was significantly higher than in the non-diabetic controls (for $p$ values, see Table 2). The mean venous $\mathrm{PO}_{2}$ in group $\mathrm{A}$ was also significantly higher than in either of the other two diabetic groups ( $\mathrm{B}$ and $\mathrm{C} ; p<0.05$ ).
In group A there was no significant difference in venous $\mathrm{PO}_{2}$ between the ulcerated and either the healed or the non-ulcerated feet.

The mean venous $\mathrm{PO}_{2}$ in the feet of the ulcerated group was also significantly higher than in the hands of the same subjects $(p<0.005)$, the other diabetics $(p$ $<0.005$ ) or control subjects $(p<0.01)$. In contrast, in the other diabetic and control subjects there was no significant difference in the mean venous $\mathrm{PO}_{2}$ between the hands and the feet.

\section{Discussion}

The results clearly show that the $\mathrm{PO}_{2}$ is increased in the dorsal foot veins of diabetics, especially those with peripheral neuropathy and past or present ulceration. Indeed, the results in this latter group were significantly higher than in either the control subjects $(p$ $<0.005)$ or the other two diabetic groups $(p<0.05)$. Though the highest results within this group were found in the feet with active ulcers, these did not differ significantly from the non-ulcerated feet or those with healed ulcers.

In the hands, in contrast to the findings in the feet, no significant differences were found between any of the groups or controls. However, the mean venous $\mathrm{PO}_{2}$ in the feet of the diabetics with foot ulcers was significantly higher than in the hands of the same subjects $(p<0.005)$, other patient groups $(p<0.005)$ or controls $(p<0.01)$. Similar comparisons between the results of other groups showed no significant differences. These observations suggest a local cause for increased oxygenation which is not dependent on the presence of active foot ulceration.

Table 2. Venous $\mathrm{PO}_{2}$ in the extremeties of all groups

\begin{tabular}{|c|c|c|c|}
\hline \multirow[t]{2}{*}{ Group } & & \multicolumn{2}{|c|}{ Venous $\mathrm{PO}_{2}(\mathrm{mmHg})$} \\
\hline & & Feet & Hands \\
\hline $\begin{array}{l}\text { A. Diabetics with } \\
\text { neuropathy } \\
\text { and foot } \\
\text { ulcers }\end{array}$ & $\left\{\begin{array}{c}\text { Active ulcers } \\
(n=10) \\
\text { Healed ulcers } \\
(n=7) \\
\text { Non-ulcerated } \\
\text { feet }(n=9) \\
\text { Mean }(n=26)\end{array}\right.$ & $\begin{array}{l}63.0 \pm 2.7^{\mathrm{b}} \\
59.7 \pm 4.0^{\mathrm{b}} \\
57.7 \pm 2.8^{\mathrm{b}} \\
60.3 \pm 1.8^{\mathrm{b}}\end{array}$ & $44.7 \pm 3.5$ \\
\hline \multicolumn{2}{|c|}{$\begin{array}{l}\text { B. Diabetics with neuropathy but } \\
\text { with no foot ulcers }\end{array}$} & $53.8 \pm 2.7^{\mathrm{a}}$ & $47.0 \pm 2.2$ \\
\hline \multicolumn{2}{|c|}{ C. Diabetics with no complications } & $52.8 \pm 2.7^{a}$ & $47.0 \pm 2.8$ \\
\hline \multicolumn{2}{|c|}{ D. Non-diabetic controls } & $45.5 \pm 1.8$ & $46.8 \pm 4.2$ \\
\hline
\end{tabular}

Results are expressed as mean $\pm \mathrm{SEM} .{ }^{\mathrm{a}} p<0.05$ compared with group $\mathrm{D} ;{ }^{\mathrm{b}} p<0.005$ compared with group $\mathrm{D}$ 
In normal subjects, the oxygenation of venous blood is dependent on three main factors [6]: the oxygen saturation of arterial blood, the oxygen consumption of the tissues, and the rate of blood flow through the tissues. For ethical reasons we have not measured routinely arterial $\mathrm{PO}_{2}$ in the small arteries of the foot. However, in two of the patients with active foot ulcers who underwent arteriography, both had normal peripheral arterial oxygen saturation. In diabetics, glycosylation of haemoglobin may cause altered oxygen affinity [7]; but since this would affect the $\mathrm{PO}_{2}$ in hand veins to the same degree as in the feet, this does not explain the present findings.

Although there are no studies in diabetic subjects, Fontaine [8] has shown that in tissues surrounding varicose ulcers oxygen consumption is increased, which might be expected to reduce venous $\mathrm{PO}_{2}$. Reactive hyperaemia in the absence of active infection can cause a local rise in venous $\mathrm{PO}_{2}$ [9]. However, this does not account for the findings in the feet with healed ulcers, or in the unaffected feet in group A.

Diabetic patients with neuropathic foot ulcers have previously been found to have increased mean blood flow in the lower limb arteries $[1,2]$. These findings, together with the increased venous $\mathrm{PO}_{2}$ described here, would be compatible with A-V shunting. Some evidence for increased $\mathrm{A}-\mathrm{V}$ shunting in diabetic subjects has been provided by Partsch [10] using labelled human albumin microspheres. The foot has many pre-existing A-V shunts [11] which are not fixed in number and which may form in response to an increased blood flow [12]. Although the functional control of these shunts is not fully understood, they have a rich sympathetic nerve supply. However, there is much disagreement over the frequency of involvement of peripheral autonomic fibres in diabetic neuropathy [13-15]. None of the patients studied had symptoms suggestive of autonomic neuropathy and all had a Valsalva ratio of $>1.21$, apart from three patients with ratios between 1.1 and 1.2. Nevertheless, autonomic neuropathy is frequently patchy in distribution and thus it is possible that local sympathetic damage may occur.

Thus, these findings, which are compatible with increased $\mathrm{A}-\mathrm{V}$ shunting, may be secondary to a functional abnormality of lower limb vessels, perhaps induced by local sympathetic neuropathy or increased arterial blood flow.

Further studies are needed in order to determine whether this simple technique can be used to identify patients at risk of ulceration, and whether by phar- macological means it is possible to reverse the effect by modifying sympathetic outflow to the lower limb vessels.

Acknowledgements. We wish to thank Dr. R.A.Dixon of the Department of Community Medicine for his advice on the statistical analysis and also Mr. L. Wilbourne, Perfusion Technician.

\section{References}

1. Partsch H (1978) Gestörte Gefäßregulation bei ulzeromutilierenden Neuropathien der unteren Extremitäten. Vasa 7: $119-125$

2. Scarpello JHB, Martin TPR, Ward JD (1980) Ultrasound measurements of pulse-wave velocity in the peripheral arteries of diabetic subjects. Clin Sci 58: 53-57

3. Scarpello JHB, Martin TPR, Ward JD (1980) Blood velocity studies in diabetic subjects with neuropathic ulcers. Clin Sci Mol Med 55: 3 P

4. YaoST, HobbsJT, Irvine WT (1969) Ankle systolic pressure measurements in arterial disease affecting the lower extremities. Br J Surg 56: 676-679

5. Ewing DJ, Campbell IW, Burt AA, Clarke BF (1973) Vascular reflexes in diabetic autonomic neuropathy. Lancet 2: 1354-1356

6. Rosenweig J (1955) The effect of the position of the arm on the oxygen saturation of the effluent blood. J Physiol [Lond] 129: 281-288

7. Ditzel J, Standl E (1975) The problem of tissue oxygenation in diabetes mellitus. Acta Med Scand Suppl 578: 49-68

8. Fontaine R (1957) Remarks concerning venous thrombosis and its sequelae. Surgery $41: 6-25$

9. McNeill TA (1956) Venous oxygen saturation and blood flow during reactive hyperaemia in the human forearm. J Physiol [Lond] 134: 195-201

10. Partsch H (1977) Neuropathien vom ulzero-mutilierenden. Vasa 6 (Suppl): $1-48$

11. Sherman JL (1963) Normal arteriovenous anastomoses. Medicine 42: 247-267

12. Richards RL (1970) The normal peripheral circulation. In: Richards RL(ed) Peripheral arterial disease. Livingstone, Edinburgh and London, pp 6-25

13. Martin MM (1953) Involvement of autonomic nerve fibres in diabetic neuropathy. Lancet $1: 560-565$

14. Ozeran RS, WagnerGR, ReimerTR, Hill RA (1970) Neuropathy of the sympathetic nervous system associated with diabetes mellitus. Surgery 68:953-958

15. Friedman SA, Freiberg P, Colton J (1972) Vasomotor tone in diabetic neuropathy. Ann Intern Med 77:353-356

Received: 21 January 1981

and in revised form: 19 August 1981

Dr. A.J.M. Boulton

Department of Medicine

P Floor

Royal Hallamshire Hospital

Glossop Road

Sheffield S10 2JF, UK 